\title{
Management Of Curriculum 2013 Mathematic Learning Evaluation In Junior High School
}

\author{
Sutama $^{1, *}$, Sabar Narimo ${ }^{1} \&$ Samino $^{1}$ \\ ${ }^{1}$ Postgraduate Education Administration Magister, Universitas Muhammadiyah Surakarta, \\ Indonesia \\ *Corresponding author: Postgraduate Education Administration Magister, Universitas \\ Muhammadiyah Surakarta, Indonesia. E-mail: sutama@ums.ac.id
}

Received: July 8, 2015

Accepted: August 15, 2015 Published: September 7, 2015

doi:10.5296/ije.v7i3.8335

URL: http://dx.doi.org/10.5296/ije.v7i3.8335

\begin{abstract}
The aim of this research is to decribe the management of curriculum 2013 mathematics learning evaluation on aspects: 1) affective, 2) cognitive, and 3) psychomotor performed by teachers in Junior High Schools Salatiga Central Java. This research used qualitative-ethnographic approach. The informants were headmaster, teachers, and students. Data collection techniques were observation, interview, and documentation. Data validations were technique and source triangulation, and data were analyzed by using flow method. Research results: 1) the management of mathematics learning evaluation on cognitive aspect consists of spiritual and social attitude. The evaluation on affective aspect was done through observation, teacher's journal, self-evaluation, and peer-evaluation, but not all optimum. 2) the management of mathematics learning evaluation on cognitive aspect was done by written test, oral, task; but the questions were less challenging. 3) the management of mathematics learning evaluation on psycomotor aspect was done by performance evaluation, project, and portfolio. Evaluation on psychomotor aspect tended to be done in group.
\end{abstract}

Keywords: affective, cognitive, 2013 curriculum, learning evaluation, psychomotor 


\section{Introduction}

The changing of previous national curriculum into 2013 curriculum (progressive curriculum applied since academic year 2013/2014) is a government effort to develop education in Indonesia so it will not be left behind from other countries. One of the emphases in 2013 curriculum is authentic evaluation. Accoding to Ghufron and Sutama (2011: 7.2), authentic evaluation is a form of student's performance attitude evaluation comprehensively in real situation. Curriculum 2013 emphasizes the changing in doing evaluation, namely evaluation through measurement test (measuring knowledge based on the result only) into authentic evaluation (measuring attitude competence, skill, and knowledge base on process and result).

Eight of twenty six junior high schools in Salatiga Central Java Academic Year 2014/2015 apply 2013 curriculum. Initial observation result found an imbalance in curriculum 2013 application in which mostly, mathematic teachers in Salatiga have difficulties in performing evaluation on attitude and skill attitude. Those imbalances can affect inaccurate result related to mathematic learning mastery in Junior High School. Mathematics presented to students has no enforcement value in forming complete attitude and personality. It has not formed dicipline, careful, critical, patience, care, and brave attitude optimally through mathematics learning.

Based on that idea and in emergency situation " to implement 2013 curriculum immediately", it would be wise if teacher focuses on learning management based on its need, namely developing lesson study-based curriculum 2013. Scientific approach and stresses on authentic evaluation on mathematic learning 2013 curriculum will stimulate student's knowledge in responding the environment. Lesson study is a model in forming profesional teacher by the study of learning collaboratively dan continually based on mutual learning collegiality principles to build learning community (Sutama, Haryoto, and Sabar Narimo, 2013). It is appropiate with principle of 2013 curriculum implementation namely students have to get qualified education service, and get opportunity to express themselves freely, dynamically, and fun.

In general, the first year research is aimed to describe the management of curriculum 2013 mathematic learning performed by Junior High School teachers in Salatiga Central Java. In this article, the research is aimed to describe the management of curriculum 2013 mathematic learning on aspects: 1) affective, 2) cognitive, and 3) psychomotor performed by Junior High School teachers in Salatiga Central Java.

\section{Research Method}

A. This research, as a whole, used research and development approach. The first year research used qualitative approach. Qualitative research is aimed to understand social phenomenon from participant's perspective (Sutama, 2010: 32). Research location is Junior High Schools in Salatiga Central Java in 2014/2015.

B. Research sources were informants, documents, and places or events. The informants 
were headmaster, Mathematics teachers, and students of State Junior High School 1, 2, 5, 6, 7, 8, Satya Wacana Christian Junior High School, and Junior High School Christian 2 Salatiga. Data were collected by using observation, interview, and documentation. Data validity was examined by using method and source triangulation. The data were analyzed by using flow method qualitative analysis (Flick, Kardorff, and Steinke, 2004: 266).

\section{Research Result and Discussion}

\subsection{Management of Affective Aspect Mathematic Learning Evaluation}

Management of affective aspect mathematic learning evaluation in research location is divided into spiritual and social attitude. The assessment of attitude competence was done by observation, self assessment, peer assessment, and teachers' journal. The instruments of observation, self assessment, and peer assessment were check list or rating scale with rubric. The journal was teacher's note. Rubric is criteria list showing performance, aspects will be assessed, and quality gradation (Qomari, 2008). Every assessed aspect is determined its tactic and time. Final score calculation used formula:

$$
\frac{\text { Achieved Score }}{\text { Maximum Score }} \times 4=\text { Final Score }
$$

Final score was classified based on Permendikbud (Education and Culture Ministerial Regulation) No. 81A 2013, namely score 3,33< score $\leq 4,00$ : Excellent; 2,33< score $\leq 3,33$ : Good, score; $1,33<$ score $\leq 2,33$ : Fair; or score $\leq 1,33$ : Poor. Here is brief explanation of assessment sample performed in research location schools.

The assessment of spiritual attitude competence in research location schools in mathematic learning class VIII with algebraic operation main material was done by using self assessment technique by students in the end of the lesson. Assessed indicators are 1) praying before and after doing something, 2) grateful for Almighty God's grace and gift, 3) worship on time, 4) tawakal (giving ourselves to God) after doing an effort, and 5) maintaining good relationship with all members of religious community. Scoring was done with rubric, i.e given score 4: if always do as the statement, 3: if always do as the statement or sometimes not, 2: if sometimes do and often not, or never do.

Those spiritual attitude competence assessments give systematical affective attitude assessment sample. It is done based on schedule and continually by following standard steps and using appropriate assessment rubric. It shows that final score can be transformed into attitude competence design based on valid orientation. This research result is in line with research conclusion of Wolf and Stevens (2007); Almond (2010); and Clementsa and Cord (2013), that in performing learning evaluation, we have to make assessment rubric, whether on attitude evaluation, skill evaluation, or comprehensive evaluation combined with information technology. By using learning result assessment based on determined rubric will gain accurate, fair, and objective students' learning result information. 
The spiritual attitude competence assessment is also valid. The assessment is performed based on data reflected competence will be measured. It is shown by one aspect of spiritual aspect into five indicators and each indicator is assessed based on determined rubric.

The assessment of social attitude competence at research location schools in mathematics learning class VII with the Sets as the main material, was done by using observation technique and peer assessment. Observation technique was done by the teachers during learning process. Indicators: A.1. showing curiosity which is signed by asking questions to other students or teachers during learning activity. B.1.1. showing responsibility in accomplishing task from teachers on time. B.1.2. showing responsibility in accomplishing task from teachers which is signed by students' participation in group work. Each indicator rubric shown below:

Indicator Rubric A.1. curiosity attitude, scored 1: Poor, if do not make an attempt to try or ask question or do not care during learning process; 2: Fair, if already make an atttempt to try or ask question during learning process but not cosistent yet; 3: Good, if often try or ask question in learning process, 4: Excellent, if showing an attempt to try or ask question in learning process consistently.

Indicator Rubric B.1.1. development of responsibility attitude in group means punctual in submitting task, scored 1: Poor, if more than 3 days late in submitting task; 2: Fair, if 3 days late in submitting task; 3: Good, if submitting task on time in 3 days; or 4: Excellent, if submitting task less than 3 days.

Indicator Rubric B.1.2. development of responsibility attitude in group, means student's participation in work group, scored 1: Poor, if showing no attempt to take part in doing group task ; 2: Fair, if sometimes take part in doing group task; 3: Good, if often take part in doing group task; or 4: Excellent, if taking part in doing group task continoually and consistenly.

Those assessments of social attitude competence through observation above give affective attitude assessment sample needed to be developed. Those assessments of social attitude competence directly show indicators that should be divided into several indicators described those aspects. Indicator assessment from different aspect (note A.1 and B.1.1; B.1.2) cannot be combined into one attitude. According to Matondang (2009) and Serepinah (2013) measurement result achieved is difficult to reflect real learning result. It implicates toward final score transformation into attitude competence design.

That social attitude assessment is invalid and incomprehensive. Assessment performed should be valid, means that the assessment based on the data represent ability will be measured. Assessment has to be performed comprehensively and includes all competence aspects by using various appropriate assessment technique. According to Hidayat and Patras (2013) and Rumawati, Majaya, and Noor (2014), evaluation that can monitor student's ability development and show education quality will have a role strategically in nation's foundation. Thus, we need to develop assessment of social attitude aspects as it is hoped.

Alternatives of social attitude aspects assessment development agreed together means each social attitude aspects is separated into several indicators, then each indicator is assessed 
based on given rubric. As the example, mathematic learning in certain classes with certain material will assess independence and responsibility social attitude aspects. Each social attitude aspects is separated into several indicators, and each indicator is assessed with rubric, as explained below:

Independent social attitude aspect, the indicators are: 1) coming on time; 2) obeying the school's rules/ regulation; 3) Doing/submitting task on given time; and 4) bringing needed learning tool/media by themselves. Rubric to assess each indicator are: scored 4: if always do same as the indicator statement; 3 : if often do same as the indicator statement, and sometimes not; 2: if sometimes do and sometimes not same as the indicator; or 1: if never do same as the indicator.

Responsible social attitude aspect's indicators are: 1) performing individual task well; 2) taking risk from action performed; 3) admitting and apologizing for the mistakes; and 4) Keeping promise. Rubric to assess each indicator scored 4: if always do same as indicator's statement; 3: if often do same as indicator's statement and sometimes not; 2: if sometimes do and often not do same as the indicator's statement; or 1: if never do same as the indicator' statement.

Based on each score, it's achieved total score of social attitude aspect. Final score was calculated by using determined formula, then final score was classified based on Permendikbud (Education and Culture Ministerial Regulation) No. 81A 2013. By using this assessment, it is hoped that it will fulfill assessment principle based on 2013 curriculum namely valid, fair, and comprehensive and continuity, open, systematic, criteria-based, accountable, and educative.

Assessment performed should be valid, means assessment is based on data reflecting the ability wanted to be measured. An objective assessment is an assessment based on clear procedure and criteria and may not be influenced by assessor's subjectivity. A fair assessment means it does not advantage nor harm the students just because the students have special needs or different background. Comprehensive assessment is the teacher becomes one of inseparable components in learning activity. Assessment has to be transparent in which assessment criteria and the basic of decision making used can be known by all parties.

Assessment must be done comprehensively and continually, means that it includes all competence by using various appropriate assessment technique. Assessment performed by the teacher must be planned and performed on stages by following standard steps. Criteria-based assessment means that the assessment performed based on determined competence achieved standard. An accountable assessment is an assessment in which its process and result can be guaranteed its technique, procedure, and result. That assessment must fulfill educative principle if the assessment performed for students' interest and development.

Peer assessment technique is performed by the students to assess their friends through observation during learning process for the last two weeks. The indicator: showing cooperative ability in doing group task related to material about the definition of Sets. The 
instrument sample is in Figure 1.

The peer assessment in social attitude competence assessment gives example of affective aspect assessment that needs to be revised. This social attitude competence assessment directly shows the indicator, then the instrument shows the aspect. In researchers' opinion, it should be reserved i.e. determine which aspect want to be assessed, then that aspect is separated into several indicators will be assessed. Thus, it shows the cooperative ability in doing group task related to Sets definition material. Instrument valued is called indicator.

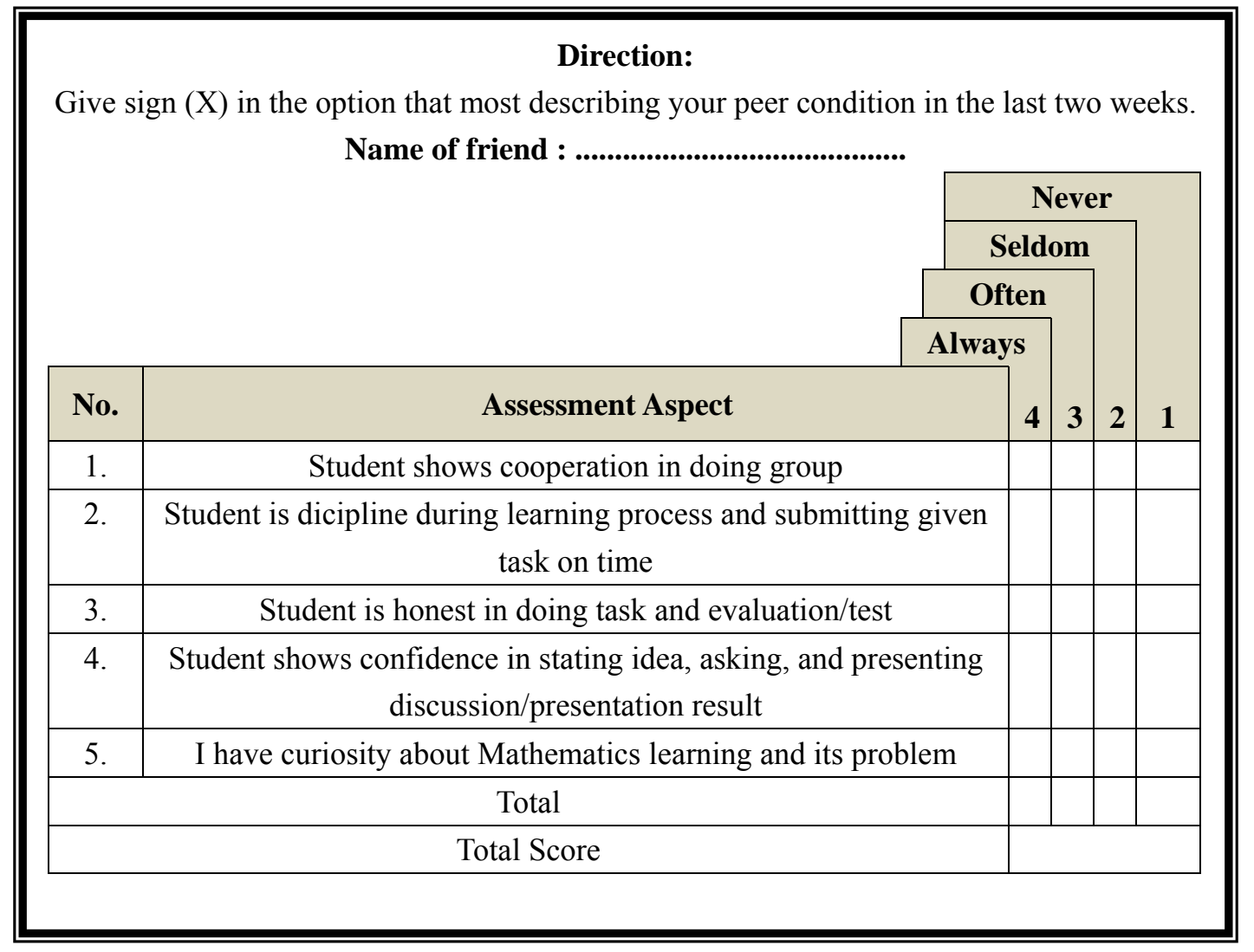

Figure 1. Instrument of Social Attitude Peer Assessment

\subsection{Management of Cognitive Aspect Mathematics Learning Evaluation}

Management of cognitive aspect mathematics learning evaluation at research location schools in cognitive aspect was done through written test, oral, and task, but the questions were less challenging. It means that the problems given in evaluation process, final, and task have not oriented on high difficulty level, important, and beneficial in the future. Especially in tasking, it would be better to give learning instruction. Mathematic teachers in research location schools have not considered that yet.

Mathematic teachers in research location schools give oral test in learning process. Written test is in the end of learning in form of multiple choice and essay. In performing written test, teachers prepare indicators to be made into questions, instrument with its answer key, but have not made assessment rubric. Here are sample questions and answer key: 


\section{Questions}

1. The sum of $(3+2 x-5 y)$ and $(17 y+9 x-7)$ is.......
a. $7 x+12 y$
c. $11 x-12 y-10$
b. $11 x+12 y-4$
d. $19 x+4 x-4$

2. Evaluate two forms of algebra multiplied resulted 15x-12xy.

3. One of factors of $3 x^{2}-x-10$ is ......
a. $3 x-5$
c. $x+5$
b. $3 x+2$
d. $x-2$

\section{Simplify algebra form $7 a(1+2 b)-3 b(1+a)$}

\section{Answer Keys:}

1. b. $11 x+12 y-4$

2. Possible answer:
a. $3 \mathrm{x}(5-4 \mathrm{y})$
b. $3(5 x-4 x y)$
c. $\mathrm{x}(15-12 \mathrm{y})$

3. d. $\mathrm{x}-2$

4. $7 a(1+2 b)-3 b(1+a)=7 a+14 a b-3 b-3 a b=7 a-3 b+11 a b$

Cognitive competence assessment above needs to be developed in line with Assessment Approach based on Curriculum 2013. It is a standard reference and learning mastery. In implementing 2013 curriculum in assessment aspect, all competence needs to be assessed by using standard reference based on learning result indicators. At first, schools have to determine standard reference appropriate with the its condition and needs. Learning mastery based on 2013 curriculum is determined as Table 1.

Table 1. Learning Mastery and Score Conversion Based on 2013 Curriculum

\begin{tabular}{cccl}
\hline \multirow{2}{*}{ Title } & \multicolumn{3}{c}{ Competence Score } \\
\cline { 2 - 4 } & Knowledge & Skill & Attitude \\
\hline A & 4 & 4 & Excellent \\
A- & 3.66 & 3.66 & \\
B + & 3.33 & 3.33 & Good \\
B & 3 & 3 & \\
B- & 2.66 & 2.66 & \\
C + & 2.33 & 2.33 & Fair \\
C & 2 & 2 & \\
C- & 1.66 & 1.66 & \\
D+ & 1.33 & 1.33 & Poor \\
D & 1 & 1 & \\
\hline
\end{tabular}


Explanation:

1. For Basic Competence (BC) in Main Competence (MC) -3 and MC-4, student can be said has not mastered the learning if showing indicator score $<2.66$ from formative test result.

2. For $\mathrm{BC}$ in $\mathrm{MC}-3$ and $\mathrm{MC}-4$, student can be said has mastered the learning if showing indicator score $\geq 2.66$ from formative test result.

3. For $\mathrm{BC}$ in $\mathrm{MC}-1$ and $\mathrm{MC}-2$, learning mastery performed by considering attitude aspect in MC-1 and MC-2 in all lessons. If student's attitude profile in general is in Good category based on related standard education unit.

Mean while the implication of those learning mastery requirement are 1) For BC in MC-3 and MC-4: teacher gives remedial test individually based on student's need who scored less than 2.66; 2) $\mathrm{BC}$ in MC-3 and MC-4: teacher gives opportunity to students who scored 2.66 or more than 2.66 to continue their study to the next BC, and 3) BC in MC-3 and MC-4: teacher gives classical remedial based on its need if more than $75 \%$ students scored less than 2.66; and 4) For BC in MC-1 and MC-2, counseling toward students which in general their attitude profile have not categorized as Good holistically (at least by teachers, Guidance and Counseling teachers, and parents).

Task form given by mathematic teachers in research location school needs to be developed. In giving the task, most teachers have not programmed yet, means that the questions have not been chosen based on its difficulty level, essence, and benefit in the future. To determine them, in teaching, teachers must refer to students' mastery standard. Teachers must include direction in solving the questions so the students can do their task by themselves. Next, students get feedback and evaluation.

\subsection{Management of Psychomotor Aspect Mathematic Learning Evaluation}

Management of psychomotor aspect mathematic learning evaluation was done through performance evaluation, project, and portfolio. Evaluation in psychomotor aspect tends to be performed through performance and project, and sometimes without assessment rubric, as the example below:

\section{Question :}

Sketch a plane with the circumference $4 a+8 b$

\section{Answer Key:}

There are many possible correct answers of that question (Open ended problem)

Assessment above does not fulfill the characteristic of 2013 curriculum namely mastery learning, authentic, continually, criteria-based, and using various assessment technique. Each characteristic is explained briefly below:

In mastery learning for competence of knowledge and skill category (MC-3 and MC-4), 
students are not allowed to do the next task if they have not finished previous task with correct procedure and good result. Mastery learning assumption is that students can learn anything, the difference is the time needed. Slow learner students need more time to learn the same material, compared to students in general.

Authentic sees assessments and learning comprehensively. Authentic assessment must reflect real world problem, not school world, by using various ways and holistic criteria (whole competence reflects knowledge, skill, and attitude). Authentic assessment is not merely measuring what is known by the students, but also more emphasizing to measure what can be done by the students.

Continuity aims to get whole description of students' learning result development, monitor the process, improvement, and continually upgrade learning result in form of process assessment, continuity various kind of tests (daily, mid-term, final test, and promotion test).

Based on criteria reference above, students' ability is not compared to the group, but compared to determined criteria, such as minimum mastery, determined by each education unit. Assessment techniques chosen can be in the form of written, oral, product, portfolio, performance, observation, and self-assessment.

Skill aspect evaluation can be done trough portfolio by assessing collection of students' work individually. The purpose of portfolio assessment is to monitor the development of students' Mathematic skill ability by balancing aspect of knowledge ability and attitude. Below is example of portfolio assessment.

\section{Task I}

1. Mention at least 5 examples of collection/ object group in your environment which is included as Sets! Mention the members (minimum 3).

2. Mention at least 5 examples of collection/ object group in your environment which is not included as Sets! Explain why the collection is not Sets!

Portfolio assessment provides assessment rubric and assessment form. It is supported by research of Nickel (2013) and Earl and Giles (2011) which conclude that in doing holistic learning result evaluation needs to be completed with submitting students' work result (portfolio), product, and project. It shows that learning result assessment needs to be done comprehensively and continuity so it can represent students' development accurately.

\section{Conclusion}

Management of mathematic learning evaluation on affective aspect consists of spiritual and social attitude. Evaluation on affective aspect can be done through observation, teachers' journal, self evaluation, and peer evaluation, but not all of them are optimum already. Management of mathematic learning evaluation on cognitive aspect can be done through written test, oral test, and task; but the questions are less challenging. Management of mathematic learning evaluation on psychomotor aspect can be done through performance 
evaluation, project, and portfolio. Psychomotor aspect evaluation tends to be in done in group.

We express our gratitude to all parties. Our gratitude expressed to the head of DIKTI DP2M and KOPERTIS Area VI who helped us in funding this multiyear research through Post graduate Team-Research Fund. We also express our gratitude to the Director of Post graduate Program of Universitas Muhammadiyah Surakarta, and the Head of Research Organization Universitas Muhammadiyah Surakarta and staffs, who facilitated and encouraged us so we can accomplish this research. We also thank the Head of DIKPORA, headmasters, mathematic teachers in Junior High Schools of Salatiga Central Java who helped this research process so it ran as planned.

\section{References}

Almond, P. (2010). Technology-Enabled and Universally Designed ssessment: Considering Access in Measuring the Achievement of Students with Disabilities-A Foundation for Research. The Journal of Technology, Learning, and Assessment, 10(5), 1-52.

Clementsa, M.D., \& Cord, B.A. (2013). Assessment guiding learning: developing graduate qualities in an experiential learning programme. Assessment \& Evaluation in Higher Education, 38(1), 114-124. http://dx.doi.org/10.1080/02602938.2011.609314

Earl, K., \& Giles, D. (2011). An-other Look at Assessment: Assessment in Learning. New Zealand Journal of Teachers' Work, 8(1), 11-20.

Flick, U., Kardorff, E.V., \& Steinke, I. (2004). A Companion to Qualitative Research. London: SAGE Publication Ltd.

Ghufron, A., \& Sutama. (2011). Evaluasi Pembelajaran Matematika. Jakarta: Universitas Terbuka.

Hidayat, R., \& Patras, Y.E. (2013). "Evaluasi Sistem Pendidikan Nasional Indonesia". Prosiding, 2nd International Seminar on Quality and Affordable Education (ISQAE), 2013, 79-88.

Matondang, Z. (2009). Evaluasi Pembelajaran. Medan: Program Pascasarjana Unimed.

Nickel, J. (2013). Formative Assessment and Syntheses in Reflection Journals. Transformative Dialogues: Teaching \& Learning Journal, 6(3), 1-16.

Qomari, R. (2008). Model-model Evaluasi Pendidikan. Jurnal Pemikiran Alternatif Pendidikan, 13(2), 173-188.

Rusmawati, Masjaya, \& Noor, M. (2014). Evaluasi Kebijakan Pendidikan Dasar Dan Menengah (Dikdasmen) Provinsi Kalimantan Timur Dalam Rangka Pelaksanaan Program Wajib Belajar 12 Tahun Di Kota Samarinda. eJournal Administrative Reform, 2(3), 1759-1772. 


\section{Macrothink}

International Journal of Education

ISSN 1948-5476 2015, Vol. 7, No. 3

Serepinah, M. (2013). Kebermaknaan Evaluasi Program Pendidikan. Jurnal Pendidikan Penabur, 20(Tahun ke-12), 78-86.

Sutama, Haryoto \& Sabar Narimo. (2013). Contextual Math Learning Based on Lesson Study Can Increase Study Communication. International Journal of Education, 5(4), 48-60. http://dx.doi.org/10.5296/ije.v5i4.4440

Sutama. (2010). Metode Penelitian Pendidikan. Surakarta: Fairuz Media.

Wolf, K., \& Stevens, E. (2007). The Role of Rubrics in Advancing and Assessing Student Learning. The Journal of Effective Teaching, 7(1), 3-14.

\section{Copyright Disclaimer}

Copyright for this article is retained by the author(s), with first publication rights granted to the journal.

This is an open-access article distributed under the terms and conditions of the Creative Commons Attribution license (http://creativecommons.org/licenses/by/3.0/). 